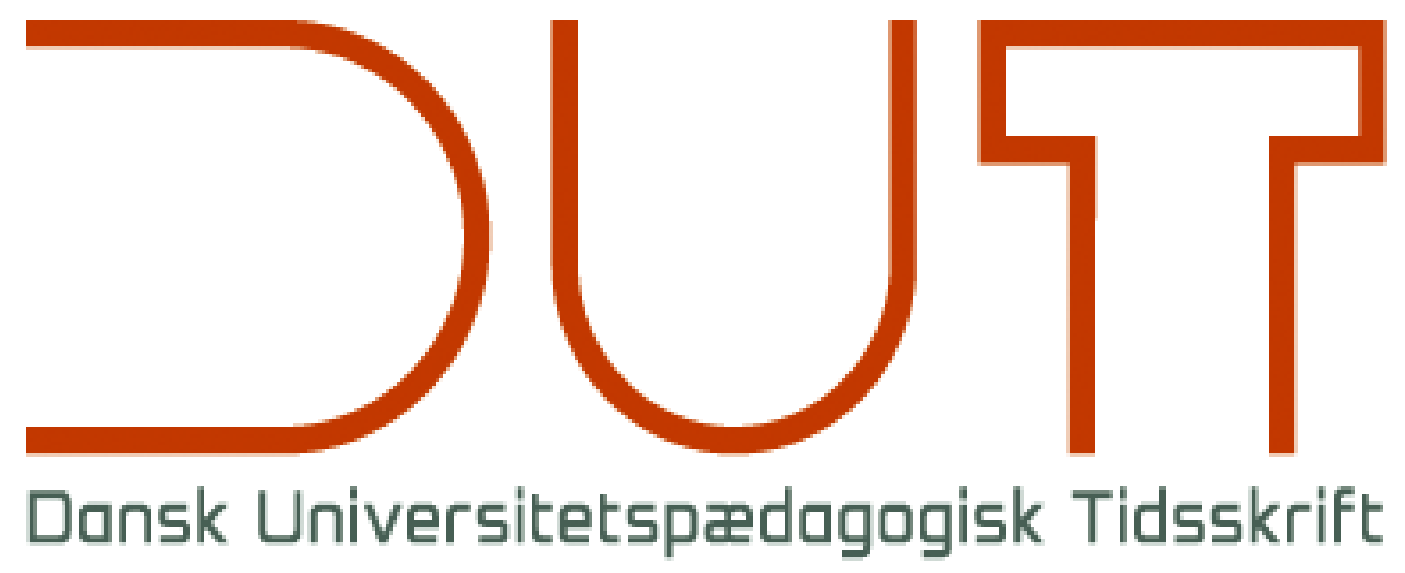

Tema

Undervisningens teknologier og teknikker

Årgang 15 nr. 28 / 2020

Titel

Digitale teknologier i dansk universitetsundervisning

- et didaktisk perspektiv

Forfattere

Sidetal

Helle Mathiasen

$1-5$

Udgivet af

Dansk Universitetspædagogisk Netværk, DUN

URL

> http://dun-net.dk/

Betingelser for brug af denne artikel

(C) Copyright
Denne artikel er omfattet af ophavsretsloven, og der må citeres fra den. Følgende betingelser skal dog være opfyldt:

- Citatet skal være i overensstemmelse med "god skik"

- Der må kun citeres „i det omfang, som betinges af formålet“

- Ophavsmanden til teksten skal krediteres, og kilden skal angives ift. ovenstående bibliografiske oplysninger.

DUT og artiklens forfatter 


\section{Digitale teknologier i dansk universitetsundervisning - et didaktisk perspektiv}

Helle Mathiasen ${ }^{\mathrm{a}, 1}$

aProfessor, Institut for Naturfagenes Didaktik, Københavns Universitet

Inviteret replik. Redaktionen har inviteret Helle Mathiasen til at skrive denne replik på baggrund af åbningsoploegget ved Dansk Universitetspoedagogisk Netvoerks Konference 2019 med temaet Undervisningens teknologier og teknikker.

I foråret 2019 fik jeg en mail fra en studerende, der sidder i Studenterrådet og i Københavns Universitets uddannelsesstrategiske råd. Den studerendes budskab var, at de studerende mangler information om, hvad digitalisering af forelæsninger betyder. De studerende er bekymrede for, at digitaliseringen vil reducere antallet af det, de kalder 'konfrontationstimer', og de er bekymrede for, om der er tale om en 'tildækket spareøvelse', som det blev formuleret. Derfor henvendte den studerende sig i et håb om hjælp til at forstå, hvad begrebet digitalisering dækker, og hvordan begrebet tænkes implementeret i undervisningen på universitetet. Som titlen antyder, har jeg i denne artikel valgt at anlægge et didaktisk perspektiv og ikke et økonomisk perspektiv med effektiviseringsrationaler som et fundament for strukturelle og organisatoriske beslutninger.

Landets universiteter har formuleret it-strategier gennem mange år, og mange begreber har trængt sig på i den sammenhæng. Ofte er de anvendte begreber hentet fra et angelsaksisk begrebsbrug, som fx digital learning, flipped learning og virtual learning. I danske universitetskontekster er der, som i resten af uddannelsessystemet og i samfundets øvrige uddifferentierede funktionssystemer, fx det politiske system, videnskabssystemet og massemediesystemet (Luhmann, 2000), gennem flere dekader blevet anvendt begreber som e-learning og blended learning. Begreberne tåler ikke en nærmere læringsteoretisk analyse, og dybest set er det problematiske betegnelser. Og hvorfor så det? Og hvorfor er det vigtigt at fokusere på det problematiske i det? Formatet for denne artikel giver ikke mulighed for en udfoldet læringsteoretisk analyse, men to centrale begreber, læring og undervisning, vil kort blive præsenteret, og med dem som udgangspunkt diskuteres begreberne digital, flipped, virtual, e- og blended learning.

Det læringsteoretiske udgangspunkt bygger på en konstruktivistisk forståelse og er inspireret af Niklas Luhmanns operative konstruktivisme (Luhmann 1998). Læring omfatter bevidsthedsaktiviteter og dermed konstruktion af viden, en proces der knytter sig til det enkelte individ som deltager i fx en undervisningskontekst på universitetet. Undervisning kan beskrives som et socialt system, et interaktionssystem, hvor eksempelvis studerende og lærere deltager med kommunikative bidrag (Luhmann 2006). Undervisning kan beskrives som en specialiseret form for kommunikation, der intenderer forandring blandt de deltagere, der har rettet deres opmærksomhed mod denne kommunikation (se Mathiasen, 2008).

Med denne tilgang til læring og undervisning, som naturligvis kan anfægtes, giver begreberne digital, flipped, virtual, e- og blended learning dybest set ikke mening i sig selv. Begreberne e-

${ }^{1}$ Kontakt: helle.mathiasen@ind.ku.dk 
learning (electronic learning) og digital learning giver associationer til en tilgang til læring som noget, der kan klares med elektroniske foranstaltninger og $\mathrm{fx}$ billeder af en studerende med en sværm af elektroder på hovedet måske endda sovende trygt i sin seng, mens de elektroniske overførsler foregår. Flipped learning er ligeledes et problematisk begreb, idet flipped kobles til begrebet læring. Virtuel betyder kunstig eller tilsyneladende (jf. Gyldendal, Den Store Danske), og når det kobles til læringsbegrebet, er der også her et oversættelsesproblem i forhold til, at det giver mening at bruge $i$ sig selv. Hvad betyder det, at bevidsthedsaktiviteter er virtuelle? Med begrebet blended learning presser endnu et spørgsmål sig på: Hvad er det, der 'blender' hos den enkelte lærende?

Begreberne kan dog blive hjulpet lidt på vej mod en meningsgivende anvendelse, set i et didaktisk perspektiv, ved at tilføje begrebet 'environments', så vi fx bruger begrebet blended learning environments og virtual learning environments. Tilsvarende vil det give mening at erstatte begrebet flipped learning med begrebet flipped classroom, hvilket også er en gængs betegnelse inden for flere didaktiske kredse. Med andre ord handler det om undervisningsog læringsmiljøer.

Lad os vende blikket mod de konkret it-understøttede lærings- og undervisningsaktiviteter. I figur 1 har jeg taget udgangspunkt i egen forskning gennem de seneste ca. 25 år ${ }^{2}$.

Figur 1: Anvendelsesoptikker

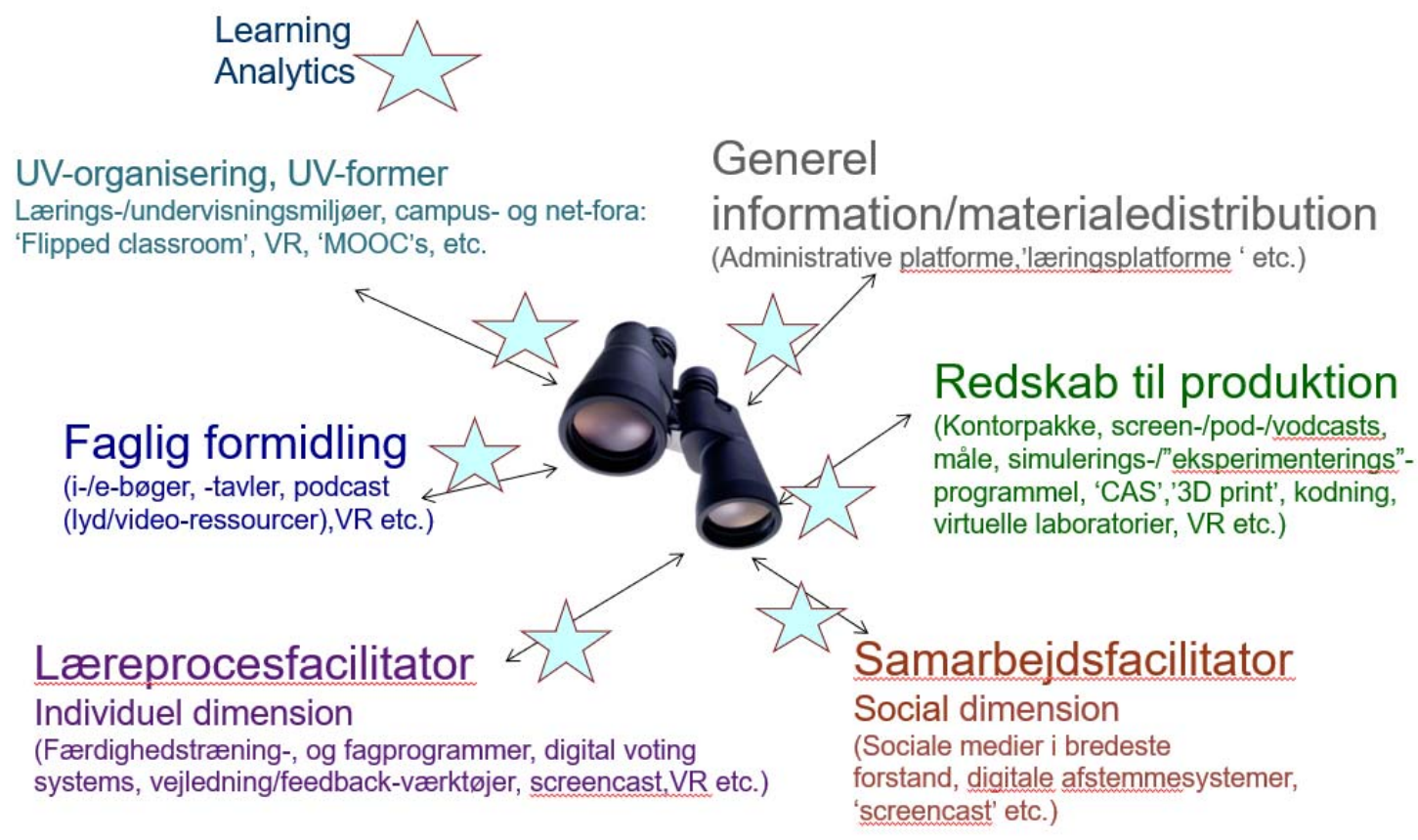

Figuren illustrerer en flerhed af optikker, når it er i spil. Det gælder de anvendte platforme som fx Canvas og Black Board (grå), de anvendte redskaber til produktion (grøn) samt itstøttede læringsressourcer til faglig formidling (blå). Net-medierede fora, som fx diskussionsfora til undervisningsrelaterede aktiviteter og sociale medier i bredeste forstand, aktualiseres under optikken med samarbejde som omdrejningspunkt (rød). Den individuelle dimension har fokus på understøttelse af den enkelte studerendes læring (lilla). Optikken med fokus på 
selve organiseringen af undervisningen og de konkrete undervisningsformer (turkis) kan aktualisere såvel on-campus undervisning som net-medieret undervisning og en bred vifte af kombinationer af disse.

Jævnfør ovenstående illustration kan samme it-ressource anvendes inden for flere optikker. I et didaktisk perspektiv, og dermed er lærerne i fokus, handler ethvert valg af teknologi om at kunne begrunde, hvorfor denne teknologi skal anvendes i den konkrete kontekst og hvordan. Et optimalt afsæt kunne være at lærerne identificerer, hvad det er for videns-, færdigheds- og kompetencemål, de ønsker, at de studerende udvikler, og gerne i samarbejde med de studerende, fulgt op af spørgsmål om, hvilke undervisningsorganiseringer og -former, der vil kunne understøtte disse mål (fysiske campusbaserede fora og net-medierede fora). Dette kan så føre til, at lærere og studerende skal foretage valg, som handler om, hvilke læringsressourcer og redskaber der kan understøtte de valgte mål.

Det er imidlertid ikke altid, at disse valg kan træffes af lærerne og studerende i den skitserede rækkefølge. En del universitetsundervisning er strukturelt og organisatorisk planlagt som fx forelæsninger, måske afviklet af forskellige lærere. Her er den konkrete undervisningskontekst fastlagt, og det er så inden for denne ramme, at lærere og studerende kan vælge bl.a. læringsressourcer, redskaber og samarbejdsfora. Det rammesætter naturligvis undervisningen (det sociale system) og dermed de muligheder, der er for valg af konkrete undervisningsaktiviteter. Og det rammesætter de studerendes mulighedsbetingelser for at nå de fastlagte læringsmål. Med andre ord har valg af undervisningsorganisering og -form betydning for understøttelsen af målene, med og uden inddragelse af diverse teknologier.

I figur 1 indgår begrebet learning analytics (LA) markeret med stjerneikonet. De seneste år har LA figureret som en faktor i forhold til uddannelsessystemets mulige beslutningsgrundlag på flere systemniveauer. LA er baseret på algoritmer, der 'trænes' på 'datasæt', der er 'fortidige', og som oftest anvendes til forudsigelser om fremtiden. LA kan have værdi for såvel studerende som lærere, fx når LA tilbyder de studerende et personligt dashboard med udtræk af information om egne aktiviteter og vurdering af disse. Læreren kan få et overblik over de studerendes aktiviteter, leveringer og vurderinger af disse (fx https://tauu.uu.nl/2018/07/ first-experiences-with-a-uu-developed-learning-analytics-platform/).

Disse informationer kan høstes via den anvendte platform, men også via figur 1's anvendelsesoptikker (jf. lyseblå stjerner). Pointen er, at LA kan tjene forskellige tilgange til undervisning og læring. Det handler om et kontinuum i forhold til tilgange til anvendelse af informationer. I den ene ende af spekteret er der fokus på intentionen om kontrol via informationer, og i den anden ende af spekteret handler det om et fokus på understøttelse af de studerendes læring via informationer fra de anvendte ressourcer.

Et eksempel på konkret brug af LA i mindre skala er anvendelse af clickers (mobiltelefon) til formativ understøttelse af de studerendes læring og ikke som en teknologi til kontrol af $\mathrm{fx}$ tilstedeværelse og antal rigtige svar på de stillede spørgsmål (Mathiasen, 2015). Den enkelte studerendes brug af clickers i forbindelse med respons på lærerens spørgsmål var ikkeanonyme og kunne dermed spores tilbage til hver enkelt studerede. De studerende og underviser havde foretaget en forventningsafstemning, hvilket betød, at studerende faktisk forventede, at læreren med de informationer, han nu kunne tilgå, aktivt ville bruge disse og tilpasse undervisningen og vejledning til den enkelte studerende. 
Det konkrete valg af kombinationer mellem kontrol af studerendes aktiviteter og understøttende ressourcer til udvikling af de studerendes læring og læringsprocesser kan eksekveres på flere organisatoriske niveauer. Det kan fx som i ovenstående eksempel dreje sig om en holdkontekst med et læringsunderstøttende formål. LA kan naturligvis også implementeres på institutniveau og på institutionsniveau og med andre formål. (Christiansen et al, 2019)

Der kan lidt kategorisk identificeres to tilgange til it-anvendelser i uddannelsessystemet - set i et didaktisk perspektiv. Den ene tilgang har fokus på didaktisk nyskabende aktiviteter, lærings- og undervisningsressourcer og gentænkning af undervisningsorganisation og mulighed for at aktualisere en vifte af undervisningsformer. Den anden tilgang kan betegnes som didaktisk konserverende, hvor it-anvendelser bruges i kendte (traditionelle) undervisningsrammesætninger som understøttende disse kendte lærings- og undervisningsmiljøer. (se fx Mathiasen, 2002, Mathiasen et al 2011, 2012, 2013, 2014, Dohn \& Hansen, 2016)

De to hårdt optrukne tilgange inviterer til fortsat diskussion om, hvorvidt it-anvendelser $\mathrm{i}$ bredeste betydning og LA specifikt kan bidrage til understøttelse af de studerendes mulighed for at lære det, der fordres i de konkrete undervisningskontekster. En start kunne være at generere en begrebsafklaring blandt aktørerne i det universitetspædagogiske felt og desuden sætte fokus på læreres og studerende forventninger til den daglige undervisning eksempelvis ved at prioritere kommunikation om teknologivalg og begrundelserne for disse valg.

It tilbyder sig, men det er os, med vores tilgange til undervisning, der er afgørende for de aktuelle valg og fravalg af teknologier. Pointen er, at det drejer sig om at fokusere på undervisnings- og læringsmiljøer og dermed et fokus på begreber, som fx flipped classroom og blended learning environment, deres betydning for undervisningsaktiviteter og deres konkrete implementering i forbindelse med planlægning, gennemførsel og evaluering af undervisningen på universiteterne.

Der er et behov for, at studerende, universitetslærere og -ledere får sat ord på de anvendte begreber og får et fælles begrebsapparat, så alle aktører har de bedste betingelser for at tale om, forstå og bidrage til undervisningsudviklingen.

De senere år har begrebet Digital Education vundet terræn på universiteterne både nationalt og internationalt. Et nærliggende spørgsmål i den sammenhæng er, hvad det er for udfordringer, vi vil løse ved brug af de forskellige teknologier, med andre ord: Hvad er digitalisering svaret på, når vi spørger ud fra et didaktisk perspektiv?

Det er forståeligt nok, at de studerende er bekymrede, når de læser om digitalisering og de begrebsmæssige kontekster, digitalisering bliver anvendt i på universiteterne. Mit svar til den studerende blev langt, nok lige så langt som denne artikel, fordi feltet er komplekst, og der er mange interesser i spil inklusive implicitte antagelser, rutiner, vanebårne handlinger, traditioner og kulturer. En pointe, som gerne skulle stå tilbage, er, at kommunikation mellem studerende, lærere og ledere er vigtig, og at begrebsbrug defineres og udfoldes i den konkrete kontekst, så den altafgørende forventningsafstemning mellem alle aktører kan gennemføres og danne præmis for undervisningen i bredeste forstand. 


\section{Referencer}

Christiansen, F.V., Mathiasen, H. \& Johansen, M.W. (2019). Learning Analytics og udvikling af studerendes autonomi og autenticitet i Dansk Universitets Pædagogisk Tidsskrift. Vol. 15, nr.27 https://tidsskrift.dk/dut/article/view/108002

Dohn, N.B. \& Hansen, J.J.(2016).Didaktik, design og digitalisering. Kbh. Samfundslitteratur

Luhmann, N. (1988). Erkenntnis als konstruktion. Berlin: Benteli Verlag.

Luhmann, N. (2000). Sociale systemer. Kbh.: Reitzels forlag

Luhmann, N. (2006): Samfundets uddannelsessystem. Kbh.: Reitzels forlag

Mathiasen, H. (2002). Personlige bcerbare computere. Kbh: DPUs forlag

Mathiasen, H. (2008). Is There a Nexus between Learning and Teaching? Communication as a Facilitator of Students' Knowledge Construction, in C. Holtham, \& C. Nygaard (ed.) Understanding Learning-Centred Higher Education.Frederiksberg: Copenhagen Business School Press.

Mathiasen, H., Dalsgaard, C., Bech, C.W., Degn, H-P. \&. Gregersen, C. (2011). Hovedrapport 2011: Undervisningsorganisering. former og - medier på langs og tværs af fag og gymnasiale uddannelse, 1. runde. Center for undervisningsudvikling og digitale medier. Aarhus: Aarhus Universitet

Mathiasen H., Bech, C.W., Dalsgaard, C., Degn, H-P. \& Gregersen, C (2012). Hovedrapport 2012: Undervisningsorganisering. former og - medier på langs og tværs af fag og gymnasiale uddannelse, 2.runde. Center for undervisningsudvikling og digitale medier. Aarhus: Aarhus Universitet

Mathiasen H., Bech, C.W., Dalsgaard, C., Degn, H-P., Gregersen, C. \& Thomsen, M. B. (2013). Hovedrapport 2013: Undervisningsorganisering, former og - medier på langs og tværs af fag og gymnasiale uddannelse, 3. runde. Center for undervisningsudvikling og digitale medier. Aarhus: Aarhus Universitet

Mathiasen, Aaen, J. H., Dalsgaard, C., Degn, H-P. \& Thomsen, M. B. (2014). Hovedrapport 2014:Undervisningsorganisering. former og - medier på langs og tværs af fag og gymnasiale uddannelse, 4.runde, 2012-2014. Center for undervisningsudvikling og digitale medier. Aarhus: Aarhus Universitet

Mathiasen, H. (2015). Digital Voting Systems and Communication in Classroom Lectures - an empirical study based around physics teaching at bachelor level at two Danish universities. Journal of Interactive Media in Education. 


\title{
Samskabelse i Praksis \\ - erfaringer fra et undervisningsforløb
}

\author{
Vibeke Andersson ${ }^{\mathrm{a}, 1}$, Helene Balslev Clausen ${ }^{\mathrm{b}}$ \\ anstitut for Kultur og Globale Studier, Aalborg Universitet \\ bInstitut for Kultur og Læring, Aalborg Universitet
}

Faglig artikel, fagfællebedømt

\begin{abstract}
Artiklen er en beskrivelse af et undervisningsforløb og de overvejelser og refleksioner, vi har gjort os i vores samarbejde med eksterne partnere. I forløbet skulle de studerende samarbejde med en virksomhed, løse en opgave for virksomheden og 'pitche' deres forslag som en del af eksamensformen. De skulle bruge deres faglige og analytiske kompetencer som en del af det forberedende arbejde, inden de afleverede den færdige rapport til samarbejdspartnerne. Det vil sige de studerende fik eksplicit bevågenhed på, hvilke kompetencer de havde i spil. Samtidig var samarbejdet med virksomhederne også en integreret del af kursusundervisningen på semestret, forstået på den måde, at de temaer, teorier og begreber, som vi tog op, kunne bruges af de studerende $\mathrm{i}$ deres senere arbejde med virksomhederne, både praktisk og teoretisk.
\end{abstract}

\section{Introduktion}

I efteråret 2018 introducerede vi nye undervisningsinitiativer og eksamensformer på 9. semester på Global Refugee Studies (GRS) på Aalborg Universitet. Forløbet er åbent for studerende på kandidatuddannelserne GRS og Turisme, begge Aalborg Universitet. Vi kalder forløbet Mobility-semesteret. Der undervises på engelsk, og hovedparten af de studerende er internationale, hvilket skaber et interkulturelt og tværdisciplinært undervisningsmiljø. De studerende kommer fra mange forskellige bacheloruddannelser, men har haft et år (7. og 8. semester) på deres respektive kandidatuddannelser. Udfordringen på dette semester er, at de nu skal samskabe (Thøgersen, 2011) opgaver fra to forskellige fagligheder - den humanistiske og samfundsvidenskabelige. Det har for os, som undervisere, været udfordrende at tænke på tværs af fag og baggrunde og alligevel skabe en fælles læringsplatform, som de studerende kunne arbejde ud fra. Denne platform skabes i løbet af de første seks uger af semestret, hvor der er kursusundervisning.

Jeg tror vi kan loere af hinanden på tvaers af de to programmer, de fleste af emnerne var overlappende

(Studerende H, 15. januar 2019)

Ud over at være et undervisningsforløb danner vores interaktion med de studerende også baggrund for og er integreret $\mathrm{i}$ et forskningsprojekt. Vi interviewede derfor de studerende efter forløbet, og til spørgsmålet om, hvad der var anderledes ved dette semester i forhold til foregående semestre, siger en studerende:

${ }^{1}$ Kontakt: van@cgs.aau.dk 
Vi kom et skridt videre i forhold til teorierne; hvad vi gjorde og hvordan vi anvendte dem. I begyndelsen [af semestret] troede jeg, at vi skulle gøre, som vi plejede, men vi tog det faktisk et skridt videre. Det gjorde, at jeg forstod teorierne bedre. Og vi kom ud i praksis, så jeg har loert at se tingene fra flere sider, fra flere perspektiver. Det har frigjort min tankeproces, så jeg er mere åben. I samarbejde med de eksterne aktører kunne vi bruge teorierne og de ideer, vi havde

(Studerende B. 15. januar 2019)

Den pædagogiske udfordring, vi vil diskutere i denne faglige artikel, er, om man i et samarbejde mellem studerende, undervisere og eksterne partnere kan samskabe et aktivt og kreativt læringsforløb (samskabelse), hvor de studerende indtager en aktiv rolle, og hvor de studerendes akademiske kompetencer bliver synliggjort, både for de studerende selv og for samarbejdspartnerne, som i dette tilfælde udgøres af en non-governmental organization (NGO), en start-up virksomhed og en kommune. Samskabelsens rammer er ikke helt fastlagt men lader sig udspringe af de studerendes indsigt i de specifikke teoretiske emner, som vi som undervisere har fastlagt på forhånd, og som udgør den fælles teoretiske læringsplatform. Vi inddrager eksterne samarbejdspartnere, ikke kun for at de studerende skal kunne forholde sig til samarbejdspartnere og deres behov, men også for at de kan blive opmærksomme på, hvordan de kan bringe deres akademiske viden og kompetencer i spil i samarbejdet med eksterne partnere. Vi vil således ikke 'kun' oprette rum for de studerende 'ude i den virkelige verden' (Gomez-Lanier, 2017), hvor de skal forholde sig til for eksempel private virksomheder, NGO'er eller kommuner, men vi etablerer et forløb, hvor de i lige så høj grad skal være bevidste om, hvad det er, de bringer med af kompetencer fra deres akademiske liv på universitetet, og hvordan disse kompetencer kan bidrage med ny viden og ideer i samarbejdet med andre, også uden for universitetet (Andersson \& Clausen 2018). Ofte når der samarbejdes med eksterne parter, lægges der vægt på hvad virksomhederne kan tilbyde. I dette semester valgte vi at arbejde med de studerende i forhold til at fremhæve, hvad deres kompetencer er i løbet af kursusundervisningen. Dette gjorde vi ved at lade dem arbejde i grupper med opgaver og eksempler i forbindelse med undervisningen. Derved blev de studerende opmærksomme på, at de kommer med akademiske og analytiske kompetencer, som de kan bruge i samarbejdet med aktører uden for universitetet, som udtrykt af en studerende her:

I stedet for et normalt semester eller praktikforløb, så er dette semester noermest en kombination - projektperioden var som et praktikforløb, fordi vi skulle løse en opgave stillet af en rigtig virksomhed, og vi skulle gøre det på en teoretisk og akademisk måde også

(Studerende G, 15. januar 2019)

Det vil sige at den studerende også bliver opmærksom på, at hun/han bringer noget viden til virksomheden/partneren, så det ikke kun er et læringsforløb om, hvordan virksomheden agerer. Læringsforløbet fremmer dermed 'employability', fordi den studerende bliver opmærksom på de kompetencer, som han eller hun selv byder ind med.

\section{Metode}

Nærværende artikel er en fremstilling af, hvordan vi formulerede, udførte og reflekterer over et undervisningsforløb. Vi var selv undervisere på forløbet. Vi vægter en empirisk fremstilling på baggrund af vores egne erfaringer med forløbet og ved brug af citater fra interviews med studerende under og efter forløbet. Den overordnede ramme for semestret er problembase- 
ret læring (PBL) (Kolmos, Krogh \& Fink, 2004; Kolmos \& Holgaard, 2007), og vi har indarbejdet PBL i flere forskellige former i løbet af semestret, som er kutyme på Aalborg Universitet. Vi har arbejdet med en virksomhed $i$ et pilotforløb i begyndelsen af semestret for at give de studerende kompetencer i forhold til at skulle arbejde med en ekstern partner i et længere projektforløb senere (se oversigt over semesteret i tabel 1). Semesteret har krævet, at vi har kunnet tilpasse os de studerendes og den eksterne partners forventninger i form af situationsbestemt projektvejledning (Kolmos \& Holgaard, 2007). Vi evaluerer løbende, interviewer studerende og indgår i samarbejde med dem, sådan at vi kan udvikle både forskning og undervisning. Vores data til denne artikel er et undervisningsforløb fra september 2018 til januar 2019 for 18 studerende på Mobility-semesteret. De studerende blev interviewet af os efter deres præsentation i pilotforløbet 3. oktober 2018, og desuden bruger vi materiale indsamlet via video-interview med de studerende efter deres semestereksamen den 15. januar 2019. Vi har lavet interviews med tre grupper efter pilotperioden (3. oktober) og interviews med alle 18 studerende efter eksamen (15. januar). Disse sidste interviews blev foretaget af en studentermedhjælper. At en tredje person, der ikke er tilknyttet undervisningsforløbet, interviewer, giver de studerende mulighed for større frihed i deres svar og kommentarer til forløbet. Alle interviews er foretaget på engelsk og oversat til dansk af os til brug i denne artikel.

\section{'Pitch' som kompetence}

Vi er blevet opmærksomme på, at vores studerende er rigtig gode til at bygge argumenter op og analysere i længere skriftlige rapporter, men at de mangler kompetencer i forhold til hvordan deres viden kommunikeres på andre måder end skriftlige rapporter. Vi inkluderede derfor seminarer, faciliteret af 'Incubators' enhenden² på Aalborg universitet, om grafisk fremstilling og hvordan man kan 'pitche' en ide på tre minutter, i vores kursusundervisning. Denne ide blev taget med hen i eksamensformen, hvor vi ikke havde en 'normal' gruppeeksamen på baggrund af et projekt, men hvor de studerende i stedet skulle 'pitche' en ide, som de havde udformet sammen med den eksterne aktør, som de havde valgt at samarbejde med. Ud over pitchet er der, i forhold til eksamen, en mere akademisk opgave, hvor de skal bringe teorier og begreber i spil, som diskuteres med eksaminator og censor i løbet af en gruppeeksamen. Men vi udformede kravene således, at teorier og begreber skulle udvælges i nøje sammenhæng med 'pitchet', og at de studerende i øvrigt skulle reflektere over deres valg (og fravalg) $i$ arbejdet med semesterrapport og pitch og i samarbejdet med den eksterne aktør for på denne måde at få de studerende gjort opmærksomme på, hvordan deres læring fandt sted, og hvordan de kan bruge en læringsproces til at opbygge kompetencer, også i deres senere arbejdsliv. 'Kompetence' er et begreb med mange definitioner (Illeris, 2011). Vi bruger begrebet, som det defineres af Illeris (2011). Han fremhæver, at "der på ingen måde findes en entydig forståelse af, hvad kompetence er, og på den anden side [er] en vis enighed om, at det - om end på forskellige måder - drejer sig om at være i stand til at handle i relation til bestemte kendte, ukendte og uforudsigelige situationer. Handlingsorienteringen står således som noget helt centralt i forbindelse med kompetencebegrebet" (Illeris, 2011, s. 33). Illeris sætter kompetencebegrebet op imod kvalifikationsbegrebet, som er løsrevet fra handlinger (2011).

2Incubators på AAU er en enhed, der hjælper studerende med at starte deres egen start-up virksomhed, mens de er studerende, og som en del af deres studie. 


\section{Semesteropbygning}

Vi opbyggede semestret i 2 moduler (se tabel 1 nedenfor). De første 6 uger var de studerende igennem tre kurser, alle relaterede til krydsfeltet mellem Turisme og GRS. Kurserne var formede som seminarer af tre til fire timers varighed, hvor vi brugte forskellige typer af undervisning: Vi talte over power points, især i forhold til præsentation af teorier, hvor de studerende forventedes at have lyttet til de talende power points og have læst teksterne, før de kom til undervisningen. I selve undervisningen havde de studerende en meget aktiv rolle. Enten havde de i grupper fået opgaver, som skulle løses og præsenteres for de andre studerende, eller vi gav dem forskellige cases, som de studerende skulle arbejde med i grupper i løbet af seminarerne og derefter fremlægge og diskutere indbyrdes i plenum.

\begin{tabular}{|c|c|c|c|c|c|}
\hline \multicolumn{4}{|c|}{ Modul 1} & \multicolumn{2}{|c|}{ Modul 2} \\
\hline $\begin{array}{l}\text { Kursus- } \\
\text { undervisning } \\
\text { Seminarer }\end{array}$ & $\begin{array}{l}\text { Pilotprojekt med start-up } \\
\text { virksomhed } \\
\text { Pitch til virksomheden } \\
\text { efter ugens forløb } \\
\text { De studerende } \\
\text { arbejder i grupper, og } \\
\text { alle arbejder med samme } \\
\text { virksomhed }\end{array}$ & $\begin{array}{l}\text { Kursus- } \\
\text { undervisning } \\
\text { Seminarer }\end{array}$ & $\begin{array}{l}\text { Eksamen i } \\
\text { kursuslitte- } \\
\text { ratur }\end{array}$ & $\begin{array}{l}\text { Projektforløb } \\
\text { Samarbejde i } \\
\text { grupper med } \\
\text { virksomhed } \\
\text { efter eget } \\
\text { valg }\end{array}$ & $\begin{array}{l}\text { Projekteksamen } \\
\text { Pitch som en } \\
\text { del af eksamen }\end{array}$ \\
\hline \multirow[t]{2}{*}{3 uger } & 1 uge & 2 uger & 1 uge & 8 uger & 1 uge (januar) \\
\hline & $\begin{array}{l}\text { Interviews med stude- } \\
\text { rende efter pilotuge }\end{array}$ & & & Vejledning & $\begin{array}{l}\text { Interviews med } \\
\text { studerende } \\
\text { efter eksamen }\end{array}$ \\
\hline
\end{tabular}

Tabel 1. Oversigt over semester

Vi brugte cases/eksempler i kursusundervisningen for at engagere de studerende og for at fremme deres kritiske tilgang til en analyse. Vi holdt også miniforelæsninger - men ikke over 20 minutter. Disse forelæsninger var altid oplæg til at inddrage de studerende - for eksempel ved at stille spørgsmål til sidst, som de studerende så skulle arbejde videre med.

Vi fik audio-proesentationer, som vi kunne lytte til på forhånd, og i seminarerne kunne vi diskutere, så vi havde mere tid til at diskutere i stedet for bare at lytte til en foreloesning [på universitetet]

(Studerende $\mathrm{H}, 15$. )

Ud over at 'vende' forelæsningssituationen (Gilboy, Heinerichs \& Pazzaglia), så de studerende skulle lytte til forelæsninger (og se power points), før de kom til undervisningen, så benyttede vi os også af andre materialer end tekst.

Ved at anvende talende power points giver man de studerende mulighed for at være aktive og byde ind med deres egne perspektiver. De kan bruge de teorier og begreber, de bliver præsenteret for i de talende power points, som de lytter til, inden undervisningen på universitetet og de cases, vi præsenterer dem for i undervisningen, til selv at uddrage/forme deres 
nye viden og anvendelse af denne. Samtidig skaber vi, i både pilotprojektet og i perioden, hvor de samarbejder med en organisation, et rum for læring uden for universitetets rammer.

\section{Pilotprojekt}

For at klæde de studerende på til at kunne arbejde på en anderledes måde, end de var vant til fra deres tidligere semesterprojekter, valgte vi at bruge en uge af kursusperioden, hvor de studerende skulle udføre en opgave for en organisation på en mere styret måde (se tabel 1). Det vil sige, at vi havde etableret kontakten til organisationen, samarbejdet med dem om tre opgaver, som de studerende skulle løse i tre forskellige grupper, og de studerende skulle så fremlægge deres ide for organisationen, undervisere og en ekstern aktør som evaluator.

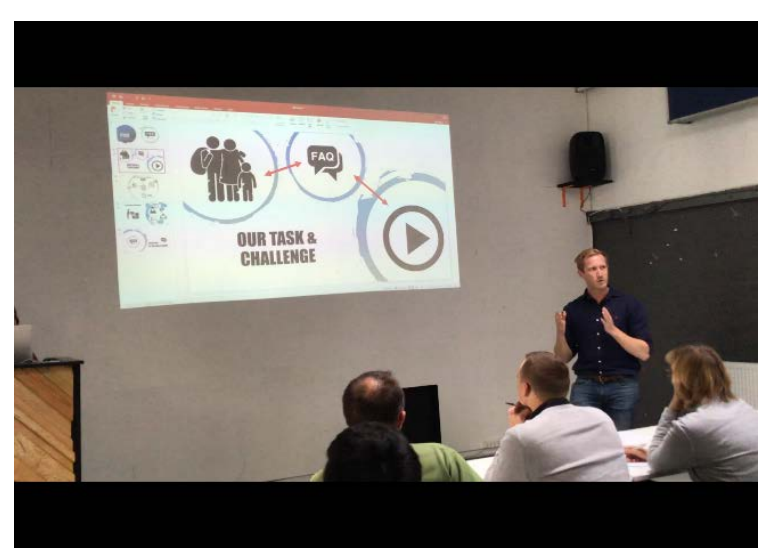

Pitch af ide til start-up virksomhed i pilotforløbet (YYY) Studenterproesentation for virksomhed i pilotperiode

Det blev et meget komprimeret forløb, og det var ikke uproblematisk for de studerende, at der var så kort tid til at løse opgaven. På den anden side vurderede vi, at det var en god forberedelse til det længere forløb, hvor de studerende selv skulle tage initiativ til et samarbejde, få en opgave og levere et resultat til en ekstern samarbejdspartner. Ved de interviews, vi foretog efter præsentationen i pilotforløbet, udtrykker de studerende nogen frustration i forhold til, at det var svært at få hold på, hvad opgaven var, hvordan den skulle løses, og hvad virksomheden forventede af dem. Det viste sig, at vi ikke havde været grundige nok i vores forberedelse af de studerende. Det skyldtes i høj grad, at vi ikke havde fået samstemt forventningerne med virksomheden. Det kræver meget forberedelse at involvere en virksomhed $\mathrm{i}$ et undervisningsforløb. På den anden side er de studerende tilfredse med deres 'produkt' og deres præsentation:

Vi lavede en video på fem dage - vi arbejdede godt under pres

(Gruppe 1, 3. oktober 2018)

På trods af svære odds, som en gruppe nævner herover, var der også tilfredshed med, at opnå et resultat på kort tid. (gruppe 3, 3. oktober 2018)

Vi havde en masse forskelligt materiale, men vi var alligevel i stand til at lave vores pitch. Det var en vigtig loering, der kom ud af dette forsøg

(Gruppe 3, 3. oktober 2018) 
Ud over at skulle fortælle om deres ide til samarbejdspartneren skulle de også bruge nye præsentationsteknikker, som de havde lært i løbet af semestret:

Det var et krav, at vi implementerede vores grafiske fordigheder, vi skulle producere visuelt materiale ved fremloeggelser. Det var ret nyt for os.

(Studerende C, 15. januar 2019)

Noget, som også kom frem i interviews efter pilotforløbet og pitchet til virksomheden, var, at de studerende blev opmærksomme på, at de i deres præsentation af en løsning blev mere fokuserede på at fremstille praktiske forslag, som 'kunne bruges':

Ja, jeg tror vi kan bruge det i vores professionelle liv - det er en lille start, men vi kan bruge det

(Gruppe 2, 3. oktober 2018)

\section{Aktiv læring}

Ved at 'vende' forelæsningen bliver underviserens forelæsning til forberedelse, sammen med læsning af undervisningsmateriale (Slomanson, 2014; Herreid, C. F. and N. A. Schiller 2013). Ud over talende power points brugte vi også podcasts (klimaforandringer), videoer (udvikling, frivillige), policy papers (NGO'er, migration, grænsekontrol) - alt sammen materiale, som de studerende skulle orientere sig i, inden de mødte op til seminarerne. Dermed skulle vi ikke bruge tid på at introducere teorier og cases, men kunne starte med at interagere med de studerende, hvor de studerende i høj grad selv var med til at forme undervisningen og pludselig kunne se nye sammenhænge, som de ikke havde været bevidste om før. Vi introducerede forløbet grundigt og fik det gjort meget klart over for de studerende, at de ikke kunne få det fulde udbytte af undervisningen, hvis ikke de var forberedt. Det er et lille hold (ca. 20 studerende), så vi havde en god fornemmelse af, at de var med, og at de fik en del ud af tværfagligheden:

Vi opdagede, at den måde vi forstår Turisme, og hvordan vi forstår 'migration, er - at faktisk synes jeg nu, at det er en del af det samme. Sådan taenkte jeg ikke på det før, men der er meget store ligheder, det er noesten det samme. Så nu forstår jeg Turisme som en fortscettelse af migration (eller omvendt), det havde jeg aldrig toenkt over før

(Studerende B,15. januar 2019)

Kurserne i grafisk fremstilling og metoder til at kunne præsentere på andre måder: illustrationer, grafik, video, infograms, viste sig nyttige:

Dette semester tillod os at vare mere kreative, at bruge kreativitet på en anden måde mere end bare akademisk. Det giver mere mening i det virkelige liv

(Studerende B,15. januar 2019)

I det andet forløb, modul 2, (efter kurserne) skulle de studerende, som tidligere nævnt, samarbejde med en organisation efter deres eget valg. Vi havde på forhånd lavet aftaler med tre organisationer; en start-up virksomhed, en NGO og et hjemløsecenter, for at de studerende havde muligheder for at vælge et af disse, hvis de ikke kunne lave aftale med en organisation efter eget valg. Perioden var ret kort (8 uger), så det var vigtigt, at de studerende kom i gang med samarbejdet hurtigt. Organisationen, som de studerende samarbejdede med, skulle 
definere en opgave, som de studerende skulle løse. Til eksamen skulle de studerende præsentere opgaven i et kort 'pitch' for undervisere og censorer.

\section{Det interkulturelle og interdisciplinære felt}

I løbet af kursusundervisningen blev vi sat i grupper, hvor vi skulle arbejde sammen med studerende fra GRS, og det var faktisk en udfordring. Vi var nødt til at forklare dem, hvad vi mente, og de var nødt til at forklare os, hvad de mente, men det er jo det gode ved det at vi skulle vore skarpe på vores egne positioner, fordi vi kom fra to forskellige studier

(Studerende C, 15. januar 2019)

Vi har lagt curriculum i krydsfeltet mellem de to fagdiscipliner (GRS og Turisme) og argumenterer for, hvordan begge fag kan byde ind med perspektiver, der skaber et nyt felt for de studerende, som opstår i samarbejdet mellem dem - som udtrykt i citaterne:

Det var interessant at loere om noget andet, forskellige emner - meget forskellige fra, hvad jeg har voret ude for før [på mit eget studieprogram]

(Studerende J 15. januar 2019)

Som nævnt tidligere, kunne studerende vælge at tage i praktik eller følge Mobilitysemesteret, men for nogle af de internationale studerende var det faktisk ikke en mulighed at tage i praktik uden for Danmark på grund af visumproblemer, og det var også svært for dem at få praktik i Danmark på grund af sproget. Der var således også pragmatiske grunde for de studerende for at vælge at følge Mobility-semestret:

I tidligere semestre havde vi mest akademiske kurser [og projekter] og så eksamen. Dette semester var en kombination af akademiske kurser og praktisk arbejde med en organisation. Og vi synes, at det hjoelper os virkelig meget, fordi de fleste af de studerende prøvede at finde en praktikplads $i$ en organisation, men vi kan ikke få visum, fordi vi kommer fra lande uden for EU, og vi havde en følelse af, at vi ville mangle noget vigtigt ved ikke at komme i praktik. Men da vi kom til undervisningen, fandt vi ud af, at det faktisk har voret meget interessant, at vi fik både det akademiske indhold og den praktiske erfaring.

(Studerende H, 15. januar 2019)

\section{Samarbejde med eksterne aktører}

Det at arbejde med eksterne partnere kræver en ekstra indsats af underviserne. Man skal opbygge en ramme om samarbejdet, så det ikke virker alt for uoverskueligt for de studerende at arbejde uden for universitetet. De bekymrer sig om format og eksamen, så det er rigtig vigtigt, at man lægger alle informationer frem, så det bliver til at arbejde med for de studerende i løbet af den forholdsvis korte tid, der er til et semesterprojekt. Arbejdet med de eksterne aktører har været med til at give de studerende en mulighed for at kunne løse opgaver, som det gav mening for dem at løse. De kunne bidrage med deres akademiske viden samt deres erfaring med projektstyring fra udarbejdelse af semesteropgaver, hvor de har arbejdet i grupper, som følge af undervisningsformen på Aalborg Universitet. Vi har således prøvet at gøre det klart for de studerende, at de allerede besad kompetencer, som kunne bruges i samarbejdet med de eksterne aktører. Samtidig har vi været omhyggelige med at briefe vores samarbejdspartnere om, hvad det var, de kunne forvente fra de studerende, og hvordan de kunne være med til at opstille rammer omkring det arbejde, som de studerende skulle 
udføre, så begge parter har haft nogenlunde afstemte forventninger i det længere projektforløb.

Vi skulle arbejde med deres ide (virksomhedens) og med hvad de ville have os til. Vi brugte vores teorier - det vi havde loert hidtil. [..] Vi var glade for at have frihed til at voere kreative

(Studerende H, 15. januar 2019)

De studerende kunne derfor bruge både de færdigheder, de havde opnået i pilotforløbet i samarbejdet med den eksterne virksomhed, og den viden, de havde opnået i de mere teoretiske forløb og i forløbet med grafiske metoder, for at nå et nyt niveau for samskabelse (Thøgersen, 2011). De kunne selv være med til at skabe nye måder at udvikle et akademisk semesterprojekt i samarbejde med en ekstern partner, så alle kompetencer kom i spil - på et nyt niveau.

Det bygger på viden, som vi har, men det giver os flere dimensioner, og vi kan faktisk selv skabe disse dimensioner ved at bruge teorier og erfaringer fra praksis. Vi var faktisk i vores projekt nødt til at opfinde nogle nye dimensioner for at få det til at virke

(Studerende B, 15. januar 2019)

Vi finder, at de studerende får en større viden om egne kompetencer. De opdager, at de kan bringe sig selv og deres viden i spil i samarbejdet med de eksterne partnere, når de skal løse den konkrete opgave, de har fået stillet.

Vi fik mere indsigt i reelle problemer, praktiske problemer, og vi har nu mulighed for at kunne gå ud og arbejde med organisationer og virksomheder med deres faktiske problemer - det er en del af PBL, som er rigtig interessant

(Studerende F, 15. januar 2019)

I løbet af den længere semesteropgave samarbejdede vores studerende, som tidligere nævnt, med tre typer af eksterne samarbejdspartnere; den start-up-virksomhed, som vi samarbejdede med i vores pilotforløb, med en NGO i Københavnsområdet, som vi også havde formidlet kontakt til, og med Esbjerg kommune.

De studerende fik forskellige opgaver med hhv. at foreslå en HR-organisation til virksomheden, at lave en promotionsvideo til NGO'en og udvikle en kyststrategi til Esbjerg kommune ${ }^{3}$. Vi havde på forhånd gjort os nogle overvejelser om, hvilke organisationer og firmaer, der kunne være interessante at samarbejde med - og som kunne være interesserede i at samarbejde med os. De studerende sagde, da de blev interviewet efter eksamen, at det havde været vigtigt for dem, at der allerede var gjort et arbejde for at finde interesserede samarbejdspartnere.

Studentermedhjoelper (SM): Hvordan har dette semester adskilt sig fra tidligere semestre på Aalborg Universitet?

Studerende E: På den måde, at vi arbejdede med en rigtig organisation, og at denne organisation var meget aktiv og interesseret. Vi har arbejdet med eksterne samarbejdspartnere

${ }^{3}$ https://jv.dk/artikel/studerende-turisme-på-fanø-skal-være-grønnere 
før, eller der var forsøg på det, men den organisation, vi tidligere arbejdede med, var ikke så engageret.

SM: Så de var mere engagerede denne gang?

Studerende C: Ja - det føltes faktisk, som om vi var ansatte der.

(Interview 15. januar 2019)

\section{Diskussion}

Ovenstående lille uddrag af interview med en gruppe studerende efter deres eksamen viser, at de studerende har oplevet en anden grad af engagement i samarbejdet med virksomhederne end tidligere. En grund til dette kunne være, at de studerende fik mulighed for at byde ind med løsninger, som virksomheden gerne ville have. En svaghed i denne faglige artikel er, at vi ikke har interviewet de organisationer, som de studerende arbejdede sammen med. Det ville have givet mere substans til vores argumentation om, at de studerende faktisk bød ind med noget. På den anden side ser vi, at de studerendes ideer faktisk bliver implementeret af nogle af organisationerne (for eksempel Esbjerg kommune).

Vores arbejde med nye undervisnings- og læringsformer, nye (mere formelle) samarbejder med eksterne aktører og nye eksamensformer har selvfølgelig givet anledning til en række refleksioner. I det datamateriale, vi har fra vores interviews med de studerende og som undervisere på semestret, har det været tydeligt, at de studerende har været glade for det nye format.

Eksamensformen var også en opbygning af kompetencer for de studerende, idet de skulle pitche deres ide. Denne måde at præsentere resultater på, er noget de kan tage med sig videre, når de skal præsentere en ide i andre sammenhænge.

\section{Konklusion}

Vores pædagogiske problemstilling var, om man i et samarbejde mellem de studerende, undervisere og eksterne partnere kunne samskabe et aktivt og kreativt læringsforløb, hvor de studerendes akademiske kompetencer blev synliggjort, både for de studerende selv og for samarbejdspartnerne. Vi har vist i artiklen, hvordan de studerende selv har fremhævet, at de opdagede, at de kunne bruge deres egen viden og kompetencer, dels ved at arbejde interdisciplinært på tværs af GRS og Turisme, og dels ved at skulle bringe deres akademiske viden og kreativitet i spil i samarbejdet med de eksterne partnere i henholdsvis NGO, start-up og kommune. Samtidig har vi kunnet bruge vores studerende og deres input i vores egen forskning, ligesom det, at vi har haft et længerevarende forskningsprojekt, har gjort, at vi har kunnet bruge vores egen forskning i udviklingen af nye initiativer i undervisningen.

Den viden og de kompetencer, som de studerende kan bringe med sig efter at have deltaget i Mobility-semesteret, kan på mange måder sammenlignes med de færdigheder, studerende, der er i praktik, opbygger. Vi prøver at skabe et forløb, som giver de studerende, der af forskellige grunde ikke tager i praktik, et forløb, som giver dem mulighed for at arbejde med en ekstern partner $\mathrm{i}$ et forløb, der har elementer af praktikken, men hvor det kombineres med kursusundervisning i semestrets første del. Vores erfaring er, at det kræver ganske meget af underviseren, da der skal lægges et ekstra arbejde i at skabe rammerne for arbejdet med de eksterne partnere. Vores erfaring er imidlertid også, at det skaber et interessant lærings- (og 
undervisnings-) rum for både studerende og undervisere, og at det kan gentages forholdsvis nemt, når først man som underviser har opbygget et format, der virker.

\section{Litteratur}

Andersson, V. \& Clausen H.B (2018): Alternative Learning Experiences: Co-creation of knowledge in new contexts. I: Innovative Practice in Higher Education, vol 2, 65-80.

Gilboy, M. B., Heinerichs, S. and Pazzaglia, G. (2014): Enhancing Student Engagement Using Flipped Classroom. In Journal of Nutrition Education and Behavior vol 47 no 1, 109-114

Gomez-Lanier, L. (2017). The Experimental Learning Impact of International andDomestic

Study Tours: Class Excursions that are More Than Field Trips. I: International Journalof Teaching \& Learning in Higher Education 29 (1),129-144

Herreid, C. F. \& Schiller, N.A. (2013): Case Studies and the Flipped Classroom. In: Journal of College Science Teaching vol 42, no 5, 62-66

Illeris, K. (2011): Kompetence. Hvad, hvorfor, hvordan. København: Samfundslitteratur.

Kolmos, A., Krogh, L. \& Fink, F.K. (red). (2004). The Aalborg PBL model: progress, diversity\& challenges. Aalborg: Aalborg UniversityPress.

Kolmos, A. \& Holgaard, J (2007): Situationsbaseret projektvejledning. I: Dansk UniversitetspoedagogiskTidsskrift 3, 54-62

Slomanson, W. R: Blended Learning (2014): A Flipped Classroom Experiment. In: Journal of Legal Education Vol 64, no 1, 93-102

Thomasen, I.N., Lorenzen H. \& Johnsen, S., (2019): Gruppebaserede læringsrum - rummer de læring? Studerendes oplevelser af tre forskellige læringsrum. I: Dansk Universitetspaedagogisk Tidsskrift 27, 155-176

Thøgersen, U. (2011). Samskabelse af engagement - om fastholdelse af de studerendes deltagelse i undervisning. I: Dansk Universitetspoedagogisk Tidsskrift, 10,45-51. 